\title{
ANALYSIS OF DETERMINING LOCATION INDUSTRY SUGAR FACTORY IN THE DISTRICT BLITAR
}

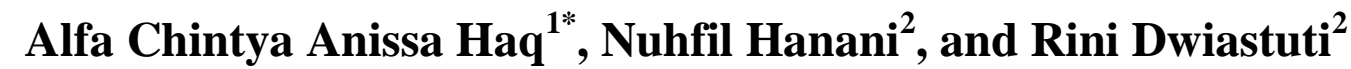 \\ ${ }^{1}$ Graduate Student, Agricultural Economic Department, Faculty of Agriculture, Brawijaya University, \\ ${ }^{2}$ Proffessor of Agricultural Economics Department, University of Brawijaya, Indonesia \\ *corresponding author: alfa.chintya92@yahoo.co.id
}

\begin{abstract}
In industrial activities, selecting the right location has an important impact on expenses both production costs and marketing costs. Development of the agricultural industry such as sugarcane production is a strategic development in Indonesia. It is important to think what should be considered to optimize the sugarcane production for supplying raw materials to the sugar factories. This study aims to analyze the important factors of location selection and to determine potential locations in Blitar. The data analyses used are factor analysis and factor rating. The results showed that the factors affecting the location selection of the sugar factory are spatial concentration, sugarcane production as a raw material for sugar factory, and physical infrastructure. Other potential locations for the construction of the sugar factory in Blitar are including the District of Nglegok, Ponggok, Binangun, Kanigoro and Wonotirto.
\end{abstract}

Keywords: sugarcane; industrial location; factor analysis; rating factor

\section{INTRODUCTION}

Among the industries development in Indonesia, agroindustry is a bridge and be a driving force for farming and agribusines development. According to the Ministry of Agriculture Strategic Plan year 2015-2019, one of the priority agenda in agricultural sector is agroindustry improvement. The purpose of this improvement is to increase productivity of the people and competitiveness in international trade. Goals for agroindustry improvement are increasing food and beverage processing GDP (Gross Domestic Product), main exported good productions, and prospective commodities. In addition, agroindustry improvement is expected to be developed mainly in rural areas for poverty reduction.

The development of sugarcane industry is so importance. It is due to the fact that sugar is consumed by majority of the people whether regarding the on-farm or off-farm production processes; and it has multi-dimentional nature of practical, social, economic and political (Estate
Directorate, 2013). Sugarcane is one of main commodity for plantation development whether for fulfilling the domestic needs or for complying exports (Estate Official of East Java, 2011).

Sugar becomes a much more needed commodity for the people and industry as well. However, problem arise as there is a lack of domestic production and demands (Direktorat General of Industry-Agro and Chemicals, 2009). National sugar consumption increases as population growth rate increasing at $1.49 \%$ each year (BPS, 2012).

To increase domestic sugar production several attempts have been conducted. These attemps includes increasing productivity at the on-farm level (sugarcane plantation) and offfarm level (low quailty raw materials and aging sugar factories without proper maintenance), as well as insufficient management improvement at factory or sugar plantation level (Mulyadi et al., 2009). As for the other attempt is to built new sugar factories (Departemen Pertanian. 2013) 
One of the initial effort to develop new sugar factory will require location selection to decide potential area to built the new facility. Research to decide industrial location selection have been used various methods. Several of them includes Analytic Hierarchy Process (AHP) to investigate location selection by giving values to the influencing factors; Location Quotient to determine base location of raw materials; Geographyc Information System (GIS) to describe spatial condition of an area (Candy and Pamungkas, 2013; Murtiningrum and Kurniawan, 2013; Fahrizal et. al, 2014). Moreover, McNamara and Henderson (2000) used Poisson Regression method to decide industrial location by supply, demand and footloose model concept which influencing the final decision for industy location. Magoddam et. al. (2010) location selection of sugar factory industry in Iran was using logit and probit models with dummy model. One of the research results shows that factor of sugarcane plantation area and sugar factory distance to the local markets will affect sugar factory location selected.

The other researches found that the industrial location selection is affected by regions characteristics. Every region will have distinct characteristics. According to Setiono (2011), the deciding factor for industrial location selection consist of sources of raw material, access to market, work force, transportation, aglomeration, site availability and condition, infrastructure, availability of energy and water, as well as government policy.

Kediri district has adequate sugarcane production. Many of the sugarcane crops were processed to sugar factories. Majority of these crops were sent to sugar factories outside of Kediri district, such as ModjopanggungTulungagung sugar factory, Ngadirejo-Kediri sugar factory and Kebon Agung- Malang sugar factory. Sugarcane plantation of Ngadirejo sugar factory are 8.000 hectare in Kediri and 6.000 hectare in Blitar (Sari, 2016). While Modjopanggung sugar factory is supported by 600 hectare area of sugarcane in Tulungagung, 100 hectare in Blitar, and 40 hectare in Trenggalek (Siska, 2014).

Based on these information there are still unused sugarcane production and have potential to be used for developing sugar factory in Blitar Regency. If new sugar factory facility being built in Blitar Regency, it is expected to absorb available sugarcane crops and local work forces as well.

\section{RESEARCH METHODS}

\section{a. Data Collection Method}

The data used in this research is secondary data based on statistics of Blitar released. The documents are published by Central Bureau of Statistics. The data collected are amount of productive work forces, work forces by the education level, sugarcane area, sugarcane production, dryland area, annual rainfall, markets distance, markets availability, water availability, wells, physical infrastructure maintenace values, communication network availability, electrical network availability, public transport availability, education services, healthcare availability, financial institutions, number of sugarcane production.

Other data used is primary data to understand the value of each factors selected. The primary data obtained by interviews with experts of sugar factory located in Kebon Agung Malang. Primary data needed for this research are based on determined variables.

\section{b. Factor Analysis Method}

Factor analysis is one of analysis based on interdepedence between variables. Factor analysis is used with the goal is to simplify several studied variables into fewer factors. Factor analysis model can be calculated by this following equations:

$\mathrm{X}_{1}-\mu_{1}=\ell_{11} \mathrm{~F}_{1}+\ell_{12} \mathrm{~F}_{1}+\ldots .+\ell_{1 \mathrm{~m}} \mathrm{~F}_{\mathrm{m}}+\varepsilon_{1}$

$\mathrm{X}_{\mathrm{p}}-\mu_{\mathrm{p}}=\ell_{\mathrm{p} 1} \mathrm{~F}_{1}+\ell_{\mathrm{p} 2} \mathrm{~F}_{2}+\ldots .+\ell_{\mathrm{pm}} \mathrm{F}_{\mathrm{m}}+\varepsilon_{\mathrm{p}}$

Or it can be writen into following matrix notation:

$\mathrm{X}_{\mathrm{pxl}}=\mu_{(\mathrm{pxl})}+\mathrm{L}_{(\mathrm{pxm})} \mathrm{F}_{(\mathrm{mxl})}+\varepsilon_{\mathrm{pxl}}$

While $\mu_{i}$ is average of variable $-i, \varepsilon_{i}$ is specific factor of $-i, F_{j}$ is common faktor of- $j$, and $\ell_{i j}$ is loading from variable of $-i$ on factor of $-j$.

There are 20 parameter used as measurement variable for location criteria of sugar factory. Determining factors and detail of the indicators can be seen on Table 3 . 
Measurement scale used in location selection of the sugar factory is ratio scale. According to Steven (1976) ratio scale is measurement of variabel which is distinguishable, had some degree of hierarchical between values, as well as assumed each variable measured from equal condition and it has absolute point-zero. Numbers on scale shows actual quantities of measured characteristic.

Kaiser Meyer Olkin test is applied to determine adequate sampling unit in order to compare the amount of parsial coefficient. Low KMO shows that correlation among pairs of variable cannot be used to describe one of the selected factors. The test is conducted by calculating KMO value, Barlett Test of Sphericity, Measure of Sampling Adequacy (MSA) and Communalities. If KMO score is < 0.50 it can be concluded that factor analysis technique is inappropriate, whereas the higher score the better use for factor analysis model.

Factor analysis will be conducted using Principal Component Analysis (PCA). After finding factors that affect selected location for sugar factory is known; then, it is followed by deciding appropriate location in Blitar Regency. The location selection is using factor rating method. Various variables are considered in location selection whether qualitative or quantitative data. Those factors have different level of urgency, therefore by giving values to the factors help to make objective decision.

\section{RESULTS AND DISCUSSION Compilling Corelation Matrix}

The result of factorization output indicates that the data obtained are sufficient to continue the next factor analysis. In the initial analysis, the KMO MSA (Kaiser-Meyer-Olkin Measure of Sampling Adequacy) was 0.292 and the test barlett's test was 700.129 with the significance level of 0.000 . The following Table 1, correlation matrix of factors affecting the determination of sugar factory locations in Blitar regency.

After conducting factor analysis in 10 phases, then it is known that the lates score of KMO MSA (Kaiser-Meyer-Olkin Measure of Sampling Adequacy) is 0.734. It exceeds $\geq 0.5$; thus, it meets minimum standard of running factor analysis. Meanwhile, Barlett's test shows
572.225 score with significance level of 0.000 thereby passing the requirement for factor analysis.

Selected variables start from 20 variables into 11 variables considering KMO. Those variables are work force on productive ages $\left(\mathrm{X}_{1}\right)$ work force based on education level $\left(\mathrm{X}_{2}\right)$, sugarcane area $\left(\mathrm{X}_{3}\right)$, sugarcane production $\left(\mathrm{X}_{4}\right)$, dryland availability $\left(\mathrm{X}_{5}\right)$, wells availability $\left(\mathrm{X}_{10}\right)$, physical infrastructure maintenace values $\left(\mathrm{X}_{11}\right)$, electrical network availability $\left(\mathrm{X}_{13}\right)$, financial institution availability $\left(\mathrm{X}_{17}\right)$, number of palm sugar unit production $\left(\mathrm{X}_{19}\right)$. More detail on test indicator based on coeeficient corelation value by KMO (Kaiser Meyer Olkin) index value and The Barlets Test of Sphericity.

Table 1. Factor correlation matrix in location selection of sugar factory in Blitar Regency

\begin{tabular}{ccc}
\hline \multirow{2}{*}{$\begin{array}{c}\text { Factoring } \\
\text { Phase of-n }\end{array}$} & \multicolumn{2}{c}{$\begin{array}{c}\text { Corelation coefficient } \\
\text { value }\end{array}$} \\
\cline { 2 - 3 } 1 & KMO Index & $\begin{array}{c}\text { the barlet test } \\
\text { of sphericity }\end{array}$ \\
2 & 0.292 & 700,129 \\
3 & 0.301 & 672,610 \\
4 & 0.372 & 665,662 \\
5 & 0.423 & 651,353 \\
6 & 0.461 & 640,139 \\
7 & 0.489 & 623,751 \\
8 & 0.630 & 595,719 \\
9 & 0.646 & 593,891 \\
10 & 0.664 & 587,244 \\
\hline
\end{tabular}

Source: Analysis results, 2017

\section{Determining Sum of Factor}

From correlation matrix analysis, it is known 10 variables affecting formed factors by reviewing PCA score result on following communalities on Table 2.

Variable with largest score namely sugarcane area coverage and sugarcane production of subdistrict in Blitar Regency each 0.946. This score means that $94 \%$ of those variables affecting the formed factors. Next the work force based on productive age (15-65 year old) and by education level (high school or equivalent) have scores each 0.921 or $92 \%$. Number of palm sugar unit production variable 
scores 0.791 or $79 \%$. Financial institution availability variable scores 0.788 or $78 \%$. Dryland availability variable scores 0.783 or $78 \%$. Electrical network availability scores 0.692 or $69 \%$. Physical infrastructure maintenace values variable scores 0.680 or $68 \%$. And the lowest score is wells availability variable with 0.504 .

Table 2. Communalities

\begin{tabular}{lc}
\hline \multicolumn{1}{c}{ Variable } & Extraction \\
\hline $\begin{array}{l}\text { Consisted of work force on } \\
\text { productive ages }\left(\mathrm{X}_{1}\right)\end{array}$ & 0.921 \\
$\begin{array}{l}\text { Work force based on education } \\
\text { level }\left(\mathrm{X}_{2}\right)\end{array}$ & 0.921 \\
Sugarcane area $\left(\mathrm{X}_{3}\right)$ & 0.946 \\
Sugarcane production $\left(\mathrm{X}_{4}\right)$ & 0.946 \\
Dryland availability $\left(\mathrm{X}_{5}\right)$ & 0.783 \\
Wells availability $\left(\mathrm{X}_{10}\right)$ & 0.504 \\
Physical infrastructure $\left(\mathrm{X}_{11}\right)$ & 0.680 \\
Electrical network availability & 0.692 \\
$\left(\mathrm{X}_{13}\right)$ & \\
Financial institution availability & 0.788 \\
$\left(\mathrm{X}_{17}\right)$ & 0.791 \\
Palm sugar unit production $\left(\mathrm{X}_{19}\right)$ & \\
\hline Source: Analysis results, 2017
\end{tabular}

Source : Analysis results, 2017

Next step is to evaluate sum sum total of eigen values more than 1 which shows those factor could explained well and must be included into the forming factors.

Table 3. Extraction Sum of Squared Loadings.

\begin{tabular}{|c|c|c|c|}
\hline \multirow{2}{*}{ Component } & \multicolumn{3}{|c|}{$\begin{array}{c}\text { Extraction Sums of Squared } \\
\text { Loadings }\end{array}$} \\
\hline & Total & $\begin{array}{c}\% \text { of } \\
\text { Variant }\end{array}$ & $\begin{array}{c}\text { Cumulative } \\
\%\end{array}$ \\
\hline 1 & 4.602 & 46.024 & 46.024 \\
\hline 2 & 2.399 & 23.992 & 70.016 \\
\hline 3 & 1.039 & 10.392 & 80.407 \\
\hline
\end{tabular}

Source: Analysis results, 2017

Extraction sum of square loading column shows how much formed factor explained the variables. If 10 selected variables combined into 1 factor then it only explained variables in $46 \%$. This value needs to be improved into 2 factor so that it produces $70 \%$ of data variation explainned. Using 3 factors have maximum score of explaining the data variation about $80 \%$.
The next phase is to classify variables into one factor. Component Matrix shows information of several variables turn into 3 factors. The listed numbers show how much loading factor which in turn shows corelation between variable and formed factor. Here is Table 4 component matrix.

First component, variable with highest loading factor is work force on productive ages (X1), work force based on education level (X2), wells availability (X10), physical infrastructure maintenace values (X11), financial institution availability (X17),number of palm sugar unit production (X19). In second component, sugarcane area (X3), sugarcane production (X4), dryland availability (X5). For third component, only electrical network availability (X13) have the highest loading score.

Tabel 4. Component Matrix

\begin{tabular}{|c|c|c|c|}
\hline \multirow{2}{*}{ Variable } & \multicolumn{3}{|c|}{ Component } \\
\hline & 1 & 2 & 3 \\
\hline $\begin{array}{l}\text { Consisted of work } \\
\text { force on productive } \\
\text { ages }\left(\mathrm{X}_{1}\right)\end{array}$ & 0.889 & 0.260 & 0.250 \\
\hline $\begin{array}{l}\text { Work force based on } \\
\text { education level }\left(\mathrm{X}_{2}\right)\end{array}$ & 0.889 & 0.260 & 0.250 \\
\hline Sugarcane area $\left(\mathrm{X}_{3}\right)$ & -0.360 & 0.893 & -0.142 \\
\hline $\begin{array}{l}\text { Sugarcane production } \\
\left(\mathrm{X}_{4}\right)\end{array}$ & -0.360 & 0.893 & -0.141 \\
\hline $\begin{array}{l}\text { Dryland availability } \\
\left(\mathrm{X}_{5}\right)\end{array}$ & -0.572 & 0.621 & 0.266 \\
\hline $\begin{array}{l}\text { Wells availability } \\
\left(\mathrm{X}_{10}\right)\end{array}$ & 0.648 & 0.058 & -0.284 \\
\hline $\begin{array}{l}\text { Physical } \\
\text { infrastructure } \\
\text { maintenace values } \\
\left(\mathrm{X}_{11}\right)\end{array}$ & 0.807 & 0.062 & 0.160 \\
\hline $\begin{array}{l}\text { Electrical network } \\
\text { availability }\left(\mathrm{X}_{13}\right)\end{array}$ & 0.392 & 0.315 & -0.663 \\
\hline $\begin{array}{l}\text { Financial institution } \\
\text { availability }\left(\mathrm{X}_{17}\right)\end{array}$ & 0.868 & -0.019 & -0.183 \\
\hline $\begin{array}{l}\text { Number of palm } \\
\text { sugar unit production } \\
\left(\mathrm{X}_{19}\right)\end{array}$ & 0.636 & 0.422 & 0.457 \\
\hline
\end{tabular}

Source : Analysis results, 2017

\section{Factor Rotation}

Factor rotation is required in order to simplify the matrix and thus easier to interpreted. Factor rotation used is varimax rotation. Varimax 
rotation is chosen because it could give better result compared to other rotation technique. Varimax rotation on table 5 produce three factor analysis result presented by analysis variables. Furthermore in this analysis, variables used are those with minimum loading factor of 0.5 .

Based on Table 5 it could be seen that 11 variables have loading factors with more than 0.5 spread in 3 factors with total sum varian percentage of $80.41 \%$. It shows that this research able to describe determining factors which affect location selection of sugarcane industry in Blitar Regency is $80.41 \%$. While the rest of $19.59 \%$ described by other factor which is not included in the model. Result interpretation based on eigen value of each factor can be described as:

1). Factor 1 (Spatial Concentration)

Factor 1 have eigen value of 4.602 and able to describe total variety of $46.025 \%$. Variables included in this factor namely

a. Population in productive age presented as available labor worker in each sub-district of Blitar Regency (loading factor 0.921);

b. Population based on educational level which become important criteria to the workforce quality (loading factor 0.921);

c. Physical infrastructure maintenance value such as roads and bridges shows asurance in term of infrastructure development in Blitar Regency (loading factor 0.680); 4) number of palm sugar unit production in Blitar Regency shows processing industry for agricultural sector tries to utilize spare crops production of neighbouring area (loading factor 0.791).

2) Raw materials factor

Faktor 2 have eigen value of 2.399 and able to describe total variety of $23.99 \%$. Variables included in this factor consist of

a. Sugarcane plantation area coverage affecting sugarcane production needed to be distributed to sugar factory (loading factor 0.946)

b. Sugarcane production in each region contributing to the raw materials supply available for sugar factory (loading factor 0.946)

c. Dryland availability show potential to expand sugarcane plantation area as attempt to increasing sugarcane production amount (loading factor 0.783 ).
3) Infrastructure Factor

Factor 3 have eigen value of 1.04 and able to describe total variety of $10.39 \%$. Variables included in this factor are :

a. Amount of wells located in each subdistrict shows water availability in the area. Sugar factory need large quantities of water for production process (loading factor 0.504)

b. Electrical network availability in Blitar Regency could support sugar factory production process (loading factor 0.692)

c. Financial institution availability such as local saving and loan cooperative in every region could help sugar company and local sugarcane farmers to cooperating. Beside, farmers also be able to easily get financial aid to increase their sugarcane production (loading factor 0.788).

Table 5. Factor Analysis Result Based on Varimax Rotation

\begin{tabular}{cccc}
\hline Factor & $\begin{array}{c}\text { Variables Which } \\
\text { Belong To } \\
\text { Factor }\end{array}$ & $\begin{array}{c}\text { Loading } \\
\text { Factor }\end{array}$ & Eigen \\
\hline F1 & $\mathrm{X}_{1}$ & 0.921 & \\
& $\mathrm{X}_{2}$ & 0.921 & 4.602 \\
& $\mathrm{X}_{11}$ & 0.680 & \\
\hline \multirow{3}{*}{ F2 } & $\mathrm{X}_{19}$ & 0.791 & \\
& $\mathrm{X}_{3}$ & 0.946 & \\
\hline \multirow{3}{*}{$\mathrm{F} 3$} & $\mathrm{X}_{4}$ & 0.946 & 2.399 \\
& $\mathrm{X}_{5}$ & 0.783 & \\
\hline & $\mathrm{X}_{10}$ & 0.504 & \\
& $\mathrm{X}_{13}$ & 0.692 & 1.039 \\
& $\mathrm{X}_{17}$ & 0.788 & \\
\hline
\end{tabular}

\section{Rating Factor}

In location selection of sugar factory industry in Blitar Regency, rating factor could be done through objective appraisal conducted by experts in sugar factory sector. Process of giving values to the determining factor in location selection based on total values given to all variables. Factors of location selection for sugar factory in Blitar Regency have higher priority as follow:

1. Spatial Concentration Factor 
Spatial concentration factor consists of determining variables such as work force with productive age, work force based on educational level, road maintenance costs, and number of palm sugar unit production in Blitar Regency. Value given to spatial concentration factor is about $39.4 \%$. This value is the highest among three determining factors. Meanwhile other spatial concentration value goes as $33 \%$ for productive-age work force; $20 \%$ for work force based on educational level; road maintenance cost have 27\%; and number of palm sugar unit production with $20 \%$.

2. Raw Material Factors

Raw material factors have given value of $34.2 \%$. Variables that affect raw material factor are namely sugarcane area coverage, sugarcane production amount, and availability of drylands. Values to each variable are sugarcane area coverage $38 \%$; dryland availability 23\%; and sugarcane production $38 \%$.

3. Infrastructure Factor

Infrastructure factor consists of water availability variable, electrical network availability, and financial institution availability. Infrastructure factor have given values of $26.4 \%$. Total sum consist of $50 \%$ from wells availability variable; electrical network varible contribute $30 \%$, and financial institution variable made $20 \%$.

\section{Location selection of Sugar Factory Industry}

Location selection of sugar factory industry is done by summed scoring values of all sub criteria to determine appropriate location based on scores. Then these scores are arranged from the highest to the lowest. Region with five highest scores will be prioritized for sugar factory industry location in Blitar Regency. As for the location selection is described on following Table 6 .

Based on Table 6, total sum of scoring could be obtained and conclusion can be taken in regard of priority location for sugar factory location in Blitar Regency. On table 6, subdistrict with highest rating score and have potential to be the location of sugar factory are Ngeglok sub-distruct with score of 1291.8; Ponggok sub-district with 1128.2; Kanigoro sub- district with 1036.8; Binangun sub-district with 907.8; and Garum sub-district with 857.6.

Table 6. Scoring of locations for sugar factory industry in blitar regency

\begin{tabular}{clc}
\hline No & Sub-District & Total Score \\
\hline 1 & Nglegok & 1291.8 \\
2 & Ponggok & 1128.2 \\
3 & Kanigoro & 1036.8 \\
4 & Binangun & 907.8 \\
5 & Garum & 857.6 \\
\hline
\end{tabular}

\section{CONCLUSIONS AND SUGGESTIONS}

Based on analysis results, it can be concluded for determining location selection of sugar factory in Blitar Regency found that factors affecting location selection of sugar factory industry are spatial concentration factor which consist of work force with productive age, work force based on educational level, infrastructure maintenance cost, and number of palm sugar unit production in Blitar Regency.

Raw material factor consists of sugarcane plantation area coverage, amount of sugarcane production, and dryland availability. Then, the infrastructure factors consist of wells availability, electrical network availability, and financial institution availability. Priority location that are approriate for developing sugar factory are located in Nglegok, Ponggok, Binangun, Kanigoro and Garum sub-district.

In building sugar factory, the investor and government should also consider work force availability in the chosen location. This is because opening the sugar factory could increase new job opportunities for local labor force. In addition, sugar factory needs large quantities of sugarcane as raw material. The sugar factory also should consider to choose the location that has enough water resources for the sugarcane processes.

\section{REFERENCES}

Joni Setiawan. 2012. Antara News : Pemkab Blitar Berencana Undang Manajemen Pabrik Gula. http://www.antaranews.com/Accessed on 15 September 2015. 
BPS Republik Indonesia. 2012 ${ }^{\mathrm{a}}$. Satitistik Penduduk 2012. Jakarta: BPS Republik Indonesia

BPS Republik Indonesia. 2012 . Satitistik Tebu 2012. Jakarta: BPS Republik Indonesia

Candy, Nanda Gayuk dan adjie pamungkas. 2013. Penentuan Alternatif Lokasi Industri Pengolahan Sorgum di Kabupaten Lamongan. Jurnal Teknik Pomits Vol. 2, No. 2, (2013).

Departemen Pertanian. 2013. Grand Strategi Pengembangan Agroindustri (Industri Pengolahan Hasil Pertanian). Direktorat Jenderal Bina Pengolahan dan Pemasaran Hasil Pertanian, Departemen Pertanian. Jakarta.

Dinas Perkebunan Provinsi Jawa Timur. 2014. Perkembangan Produksi Gula di Jawa Timur.

http://www.disbun.jatimprov.go.id/. Accessed on 15 September 2015

Direktorat Jendral Industri Agro dan Kimia. 2009. Roadmap Industri Gula. Jakarta: Departemen Perindustrian Republik Indonesia.

Fahrizal. 2015.Disertasi : Model Perencanaan Agroindustri Gula Tebu Lahan Kering Berkelanjutan Di Provinsi Nusa Tenggara Timur. Sekolah Pascasarjana Institut Pertanian Bogor.

Kementerian Pertanian. 2015. Rencana Strategis Kementerian Pertanian Tahun 2015 2019. Kementertian Pertanian Republik Indonesia.

Magoddam, Mehdi., Solayman Iranzadeh dan Hossein Bevrani. 2010.Determinants of the location choices in sugar industry of Iran: using the logit \&probit model.Agric. Econ. - Czech, 56, 2010 (9): 443-448

McNamara, Kevin T dan Jeson R. Henderson. 2000. Locatin of Food Manufacturing Plant Investment In Corn Belt Counties. Journa of Agricultural and Resource Economic 25 (2) 680-697.

Mulyadi M, Toharisman A, dan Mirsawan PDN 2009. Identifikasi potensi lahan untuk mendukung pengembangan agribisnis tebu di wilayah timur Indonesia. Pasuruan: Pusat Penelitian Perkebunan Indonesia.

Murtiningrum dan Aceng Kurniawan. 2013. Penentuan Lokasi Industri Pala Papua Berdasarkan Proses Hierarki Analitik Dan Aplikasi Sistem Penunjang Keputusan (SPK) di Kabupaten Fakfak. Agrointek Volume 7, No 2 Agustus 2013.

Sari, Sri Mas. 2016. Produksi Gula: Sistem Bagi Hasil Bakal Tak Berlaku. http://industri.bisnis.com/Accessed on 30 April 2016.

Siska. 2014. Targetkan 30 Persen Lahan Terapkan Mekanisasi pada Musim Giling 2015. http://www.ptpn10.co.id/ Accessed on 30 April 2016.

Setiono, Dedi NS. 2011. Ekonomi Pengembangan Wilayah : Teori dan Analisis. Lembaga Penelitian Fakultas Ekonomi Universitas Indonesia, Jakarta. 